\title{
Endotoxin-induced microparticle formation is subject to tolerance development in humans
}

\author{
Daniel Nguyen, Stefan Weisshaar, Michael Wolzt ${ }^{*}$ \\ From 16th Scientific Symposium of the Austrian Pharmacological Society (APHAR) \\ Vienna, Austria. 25-27 November 2010
}

\begin{abstract}
Background
Microparticles (MP) are small membrane vesicles expressing tissue factor and staining positive for annexin $\mathrm{V}$ which are released from different cell types during cell activation and apoptosis. MP are considered to promote coagulation and impair vascular function. Circulating concentrations of MP are elevated in patients with systemic inflammatory conditions.
\end{abstract}

\section{Methods}

Formation of MP was studied in 8 healthy male subjects exposed to intravenous $E$. coli endotoxin (LPS; $2 \mathrm{ng} / \mathrm{kg}$ body weight) who were re-challenged after $17 \pm 11$ days. In addition, intravenous vitamin $\mathrm{C}(25 \mathrm{~g})$ or placebo was administered 3.5 hours after LPS on alternate trial days in random order. Venous blood samples were taken before, $3 \mathrm{~h}$ and $6 \mathrm{~h}$ after LPS administration. MP were detected using FACS analysis. Leukocyte count and body temperature were measured as positive control. All results are expressed in medians in the unit $10^{3} \mathrm{MP} / \mu \mathrm{L}$ plasma.

\section{Results}

MP formation was increased $3 \mathrm{~h}$ and $6 \mathrm{~h}$ after LPS administration. However, this effect was only demonstrable after the first LPS challenge with an increase of MP from baseline 596 units [range 399-1704 units] by a factor of 1.05 at $3 \mathrm{~h}$ and 3.87 at $6 \mathrm{~h}$ after LPS, and abolished after the second LPS exposure with a decrease from 874 units [430-1404 units] by a factor of 1.17 at $3 \mathrm{~h}$ and 1.25 at $6 \mathrm{~h}$. This increase was independent of vitamin $C$ administration. In contrast, reactivity of body

\footnotetext{
* Correspondence: michael.wolzt@meduniwien.ac.at Department of Clinical Pharmacology, Medical University of Vienna, 1090 Vienna, Austria
}

temperature and leukocytosis $3 \mathrm{~h}$ and $6 \mathrm{~h}$ after LPS was similar between the study periods.

\section{Conclusions}

Our results demonstrate rapid and marked formation of MP in healthy men after systemic LPS challenge. The development of tolerance to LPS is observed in the absence of mitigated systemic inflammatory responses. This suggests that MP formation follows different pathways than those of inflammatory mechanisms.

Published: 16 November 2010

doi:10.1186/1471-2210-10-S1-A37

Cite this article as: Nguyen et al.: Endotoxin-induced microparticle

formation is subject to tolerance development in humans. BMC

Pharmacology 2010 10(Suppl 1):A37.

\section{Submit your next manuscript to BioMed Central and take full advantage of: \\ - Convenient online submission \\ - Thorough peer review \\ - No space constraints or color figure charges \\ - Immediate publication on acceptance \\ - Inclusion in PubMed, CAS, Scopus and Google Scholar \\ - Research which is freely available for redistribution

